\title{
Assessing the pocket market model for growing the local food movement: A case study of Metropolitan Vancouver
}

\author{
Terri L. Evans ${ }^{a}$ \\ Urban Studies Program, Simon Fraser University \\ Christiana Miewald ${ }^{\mathrm{b}}$ \\ Centre for Sustainable Community Development, Simon Fraser University
}

Submitted 8 July 2010 / Accepted 26 November 2010/ Published online December 2010

Citation: Evans, T. L., \& Miewald, C. (2010, December). Assessing the pocket market model for growing the local food movement:

A case study of metropolitan Vancouver. Journal of Agriculture, Food Systems, and Community Development, 1(2): $129-144$.

doi:10.5304/jafscd.2010.012.011

Copyright (C) 2010 New Leaf Associates, Inc.

\begin{abstract}
In this study we explore the pocket market model, an emergent alternative retail marketing arrangement for connecting urban consumers with local food producers. In this model, community-based organizations act as local food brokers, purchasing fresh, healthful food from area farmers and food producers, and selling it to urban consumers in small-scale, portable, local food markets. The benefits of pocket markets are numerous. They include the provision of additional and more localized marketing outlets for local food producers; increased opportunities to educate consumers about local food and sustainable food systems; the

\footnotetext{
a Corresponding author: Terri L. Evans, Urban Studies Program, Simon Fraser University, Suite 2100, 515 West Hastings Street, Vancouver, BC V6B 5K3 Canada; +1 (778) 782-7914; terri@sfu.ca

${ }^{\mathrm{b}}$ Christiana Miewald, Centre for Sustainable Community Development, Simon Fraser University, West Mall Complex, Burnaby, BC V5A 1S6 Canada; +1 (778) 782-6955; cmiewald@sfu.ca
}

convenience for consumers of having additional venues where local food is available for purchase; and an ability to increase access to fresh produce in areas with poor or limited retail food options. Despite these advantages, pocket market organizers face many challenges in implementing this model successfully. These include a lack of public familiarity with the pocket market concept, an inability to address issues of food access in a way that is financially sustainable, and issues related to logistics, site selection, and regulatory requirements.

In this paper, we will explore the pocket market model using those operating in metropolitan Vancouver (British Columbia, Canada) as an example, and assess the degree to which it addresses some of the current gaps in bringing local food to urban communities.

\section{Keywords}

alternative food networks, local food distribution, pocket market, metro Vancouver, sustainable food systems 


\section{Introduction}

Local food has made a slow but convincing return to North American cities over the past two decades. Driven by concerns about food safety and quality, the need to protect farmland from the impacts of suburban and exurban development, and complemented by questions about how growing cities and regions will feed themselves, community-based organizations have begun to grow a local food movement. The most visible expression of the movement to "buy local" food and the degree to which locally grown and raised agricultural products have found value among urban consumers is seen in the flourishing of farmers' markets across North American cities. However, there are several limitations to the farmers' market model in addressing urban residents' desire to access local food. Because farmers' markets require significant amounts of space and enough vendors to attract customers, they may not fit into all environments. Furthermore, the growth in farmers' markets means that producers are increasingly stretched to attend an ever growing number of markets, and newer markets may have difficulty attracting vendors, especially farmers, to participate. In response, a number of other strategies have been developed to shorten the gap between producers and urban consumers. In this paper, we explore the emergence of the pocket market as one such strategy.

Pocket markets are alternative retail marketing arrangements whereby community organizers serve as intermediaries who purchase locally grown and processed foods from area farmers and small-scale food producers and sell them to the public, with the goal of benefiting both producers and urban consumers. The term "pocket" is borrowed from planning practice, referencing miniature versions of urban spaces, such as "vest pocket" parks (North, 1969). Within British Columbia, Canada, pocket markets were first pioneered by FoodRoots Distributors Cooperative, a not-for-profit cooperative that distributes local and naturally grown and processed foods throughout greater Victoria. They began operating pocket markets in 2005 as a means of recognizing that "farmers were doing all that farmers could do... [and that]...they [FoodRoots] could create the link that brought small farmers and urban consumers together" (MacAdam, 2009, para. 4). FoodRoots broadly defined a pocket market as a "'mini' version of a Farmers Market" that can be run by local farmers or backyard growers selling directly to the public or through a not-for-profit organization, such as FoodRoots (FoodRoots, n.d, Sec. 2). After learning of FoodRoots's experience, four community-based organizations in metropolitan Vancouver began testing the model in subsequent years. In most instances, these pocket markets were operated by a not-for-profit organization brokering local food in support of area farmers. By purchasing local food from producers at mostly discounted rates, and then selling it to the public in small, portable local food markets, organizers in metro Vancouver refined the pocket market model to be producerindirect initiatives. It is the experience of these groups in implementing the pocket market model in this new setting and in this specific format that forms the basis of our case study.

The purpose of this paper is to (a) present the pocket market as a new model in local food retailing, (b) describe the pocket markets that operated between 2008 and 2010 in metropolitan Vancouver, and (c) describe some of the benefits and challenges of this model. In the first section, we situate pocket markets as part of the alternative food network (AFN) and then provide a description of pocket markets as they operate in metropolitan Vancouver. We then illustrate the development and implementation of the pocket market model in the metro Vancouver region. We conclude by highlighting both the benefits and the challenges of pocket markets for organizers, producers, and consumers, and provide some preliminary recommendations on how to enhance this emerging model.

\section{Background}

Pocket markets form part of the "alternative food network." AFNs support mostly small-scale farmers and local food producers by reducing the distances between "where food is grown and where it is purchased and eaten" (Jarosz, 2008, p. 232). 
This reconnection between local producers and consumers is achieved by establishing retailing outlets and initiatives where local food is prioritized, such as food cooperatives, community supported agriculture (CSA) programs, farm-to-school linkages, farmers' markets, food delivery services, and others. According to Jarosz (2008), the emergence of AFNs results from both urbanization and rural restructuring. Urban residents who no longer have direct access to agricultural land but want fresh and local food provide a customer base for small farmers who are able to sell their food for higher profit margins and with fewer retail standards (e.g., quality and quantity of produce) and regulatory requirements (e.g., liability insurance coverage) through AFNs than they would through selling to traditional retailers. This urban-rural connection provides opportunities for urban dwellers to both support rural farmers and purchase "good food" (Alkon, 2008; Connell, Smithers, \& Joseph, 2008).

The interest in "good food" in recent decades stems from public concern with the industrial food system and consumers' desire to exert more control over their food purchases. Fears of the effects of agricultural chemicals, the impacts of biotechnology on agriculture seen through the rise of genetically engineered foods, and the safety of mass-produced processed food has led consumers to seek out fresh, healthful food through relationbased food networks. It has been argued that AFNs help fight urban sprawl because of their support of local farmers, particularly those who are located close to urban areas (Vallianatos, Gottlieb, \& Haase, 2004). In doing so, urban residents become more than simply passive stewards of a somewhat distant hinterland. They are effectively, in the words of Slow Food founder and president Carlos Petrini, "co-producers [of their own food as their] eating contributes to the survival of landscapes and species and traditional foods..." (Pollan, 2006, p. 259).

To address this growing need for local food, community-based organizers saw an opportunity to serve as intermediaries within the food chain, an opportunity that allowed them to develop creative innovations to promote both local agriculturebased community development and local food production. This is evident not only in the growth of farmers' markets across North America, but also in the number of mobile farm stand projects that are taking shape: green carts on the streets of New York City; veggie vans on the roads of Columbus, Ohio; and pocket markets at community facilities and workplaces within metro Vancouver (see Morelas \& Kettles, 2009). Within our case study of metropolitan Vancouver, we look at how community-based organizations have developed the "pocket market" as an innovative means to market local food to urban consumers.

Pocket markets are a vehicle for increasing the availability of fresh, local food, while helping producers to reach a broader local consumer market. By "brokering" between local food producers and the public, pocket markets help farmers to remain on their fields and free them of having to spend increasing amounts of time directmarketing their own products. While farmers may trade off receiving a lower price for their produce and having less direct contact with customers to learn about their preferences, pocket markets can benefit them in a number of ways. In metro Vancouver, farmers are stretched to attend an ever growing number of farmers' markets, and therefore are limited in where and when they can afford to go to market. In some instances, attending smaller, more suburban markets did not make economic sense for farmers because they could receive a higher return at larger markets in more affluent urban areas (see Ling \& Newman, 2010). At the same time, nearly all farmers' market organizers across the region report a need to have more agricultural producers participate in markets to better meet consumer demand for local food (G. Stanley, personal communications, October 5, 2010). In addition, for farmers with small and emergent farms, the cost of participating in farmers' markets (in terms of time, investment in infrastructure such as tents, tables, a refrigerated truck, and more) may be prohibitive, especially if they cannot access the more financially lucrative urban farmers' markets. 
Therefore, pocket markets provide an added and reliable distribution outlet for local food producers while at the same time, their small scale and portability create new and unexpected locations (hospitals, university campuses, government offices) where local food is made conveniently available to the public.

In the pocket market model, community-based organizers assume many of the risks and costs of retailing local food. At the metro Vancouver pocket markets, organizers purchased food from local farmers and other food vendors at discounted prices and sold these items to the public at a price that would cover the costs of infrastructure, staff, and transportation. In most instances, food was priced at approximately the same levels as the farmer or food producer would set at a farmers' market. Community organizers also took responsibility for determining appropriate sites for locating a pocket market, sourcing and securing local product for sale, coordinating the collection and delivery of local products, setting up tents and tables, displaying products, and tracking inventory. Additionally, organizers played a role in educating the public about the products carried and the producers represented at the market. Having producer identification dis-
Figure 1. Outdoor Pocket Market

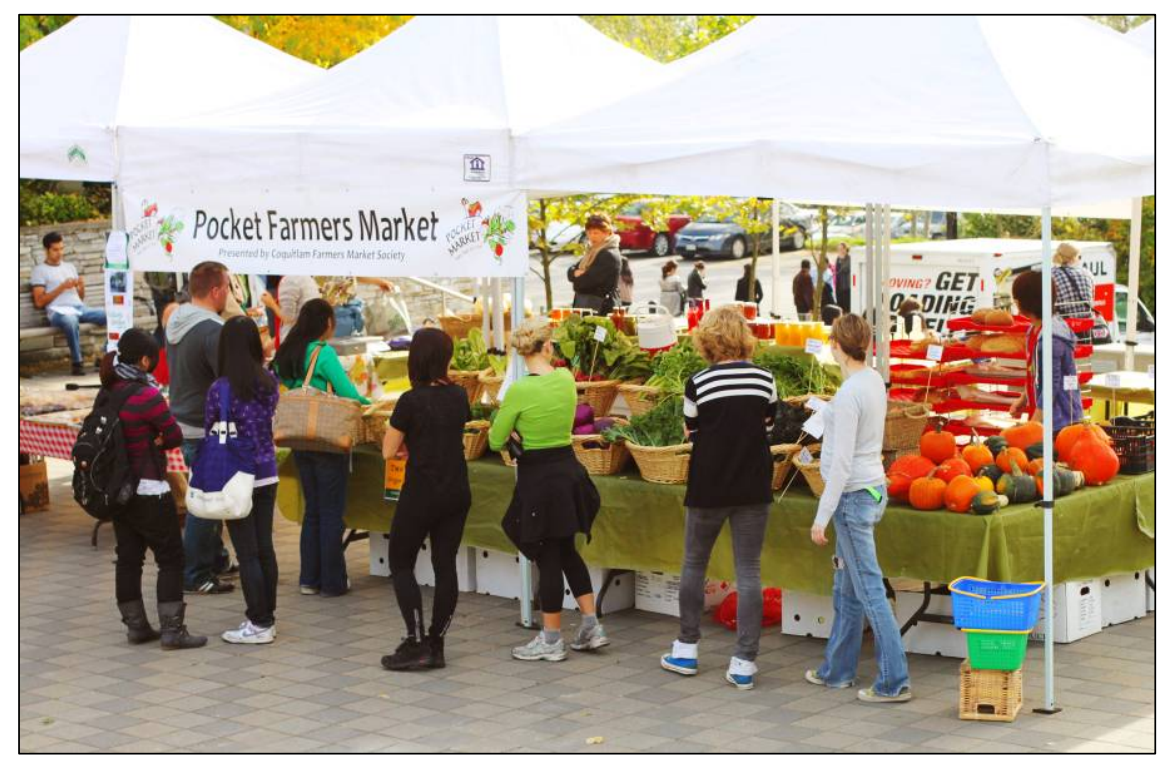

A pocket market located outdoors at a university. The target audience is staff, faculty, students, and residential community members.

Photo by Lemai Nguyen for use by the Simon Fraser University Local Food Project.

\section{Figure 2. Indoor Pocket Market}

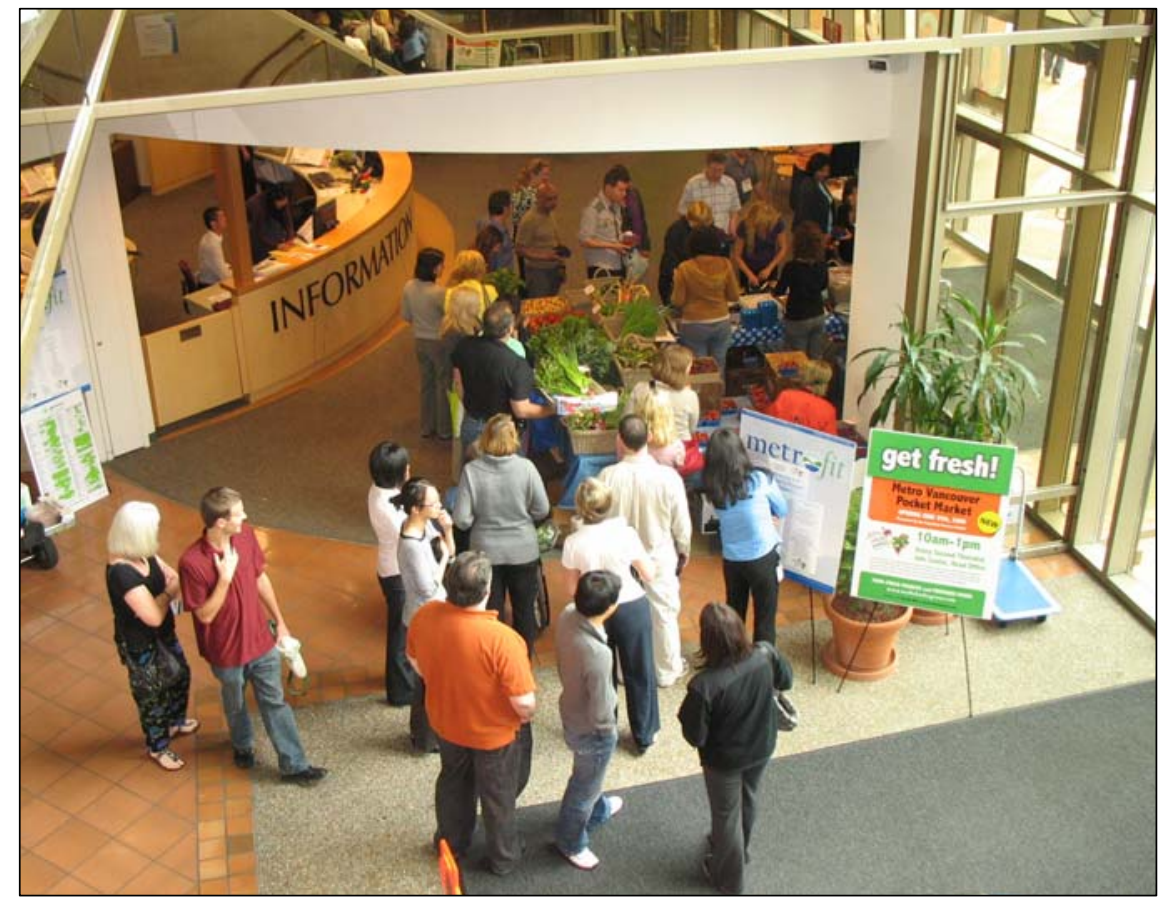

This pocket market is located in the lobby of a government office building. Its target audience is the professional and support staff who work there. The pocket market reinforces the organization's commitment to employee health and wellness.
Photo by Metro Vancouver. 
Figure 3. Indoor Pocket Market

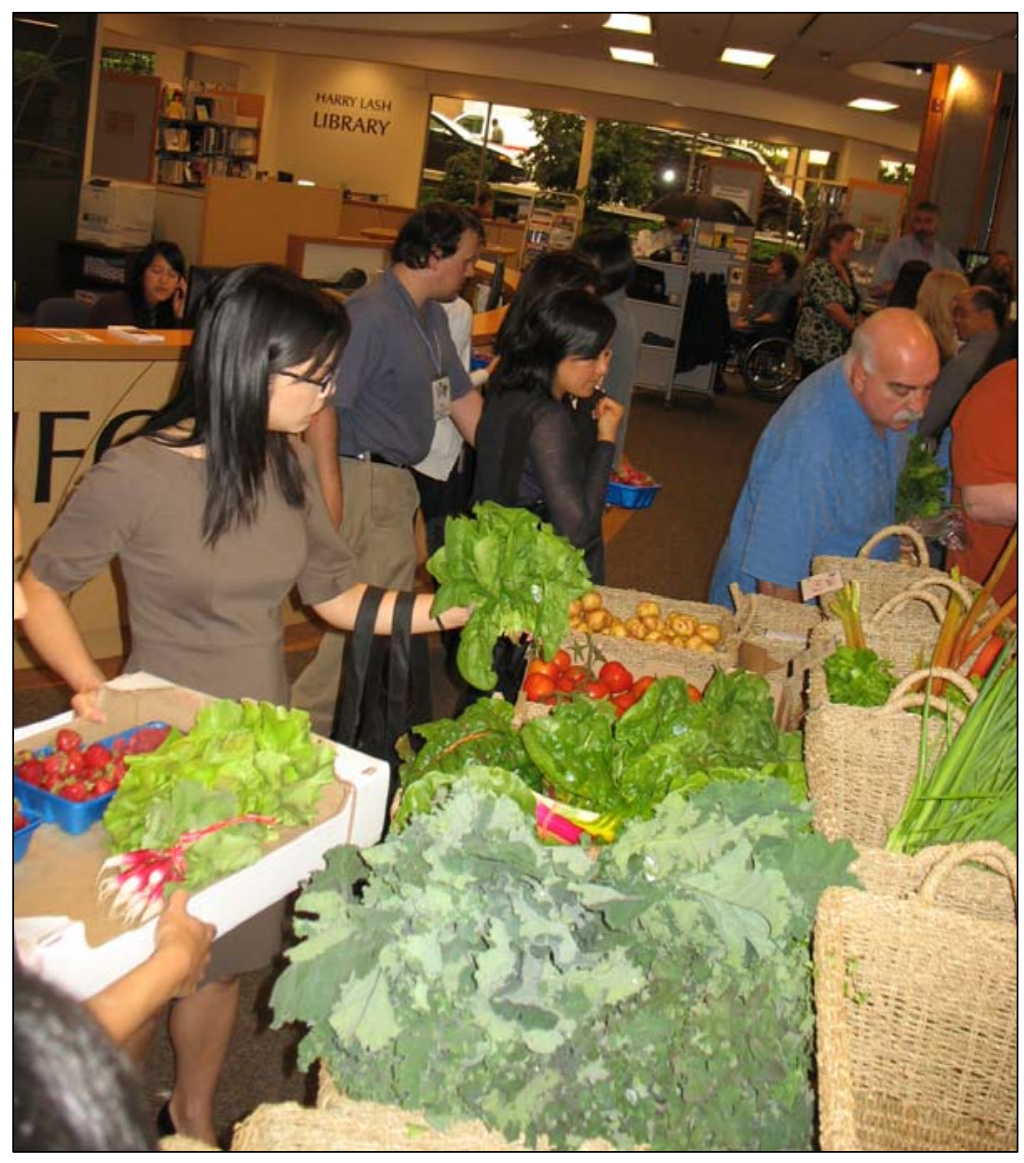

A pocket market set up in an office lobby allows people to "buy local" where they work.

played prominently throughout the market was not only an important marketing and educational tool, but was a critical element for attracting farmers to participate as suppliers to a pocket market. Thus, having well trained staff who can speak knowledgeably about the producers and their products was viewed as important for promoting sales and achieving the goals of both producers and market organizers. Producers want consumers to know them, their growing practices, and to associate freshness, quality, and in some cases, uniqueness of product, with their particular farm. This helps producers to build familiarity with their products and brand recognition among clientele who value eating local food. Pocket market organizers also had to manage excess inventory at the end of the market day, and if operating markets at multiple sites throughout the week, they had to have a place to store both perishable and nonperishable goods.

Therefore, and as will be revealed through our case study of implementing pocket markets in metropolitan Vancouver, pocket markets can help meet the public's demand for local food and also work to grow this demand. This helps to increase the likelihood that local food can be grown specifically for local consumption, contributes to increasing a region's food security, and adds further impetus (along with other AFN projects and initiatives) for orienting the agricultural sector toward a more local and regionally based economy.

\section{Case Study: Pocket Markets in Metropolitan Vancouver}

Our research into the implementation of the pocket market model in metropolitan Vancouver began with an environmental scan to determine which community groups or organizations were operating pocket markets. We discovered that four groups were involved in piloting the pocket market model in metropolitan Vancouver. These included the Richmond Food Security Task Force, the Coquitlam Farmers Market Society, the Westside Food Security Collaborative, and the Surrey Urban Farmers Market. Of these groups, the Richmond Food Security Task Force, Coquitlam Farmers Market Society, and Westside Food Security Collaborative had operated seasonal pocket markets for two or more years.

Organizations operating pocket markets in metropolitan Vancouver acquired knowledge about the model in several ways. The first way was through direct contact with representatives of FoodRoots Distributors Cooperative, who, through conversations and presentations, shared with metro Vancouver groups their experience in pioneering 
pocket markets on nearby Vancouver Island. The second way that groups learned of the pocket market model was through consulting the online toolkit that FoodRoots had developed and posted to its website. Thirdly, groups within metro Vancouver shared their knowledge of and experience with implementing the pocket market model with each other. For example, after most groups had operated pocket markets for at least one year, representatives from the Richmond, Coquitlam, and Westside groups held a teleconference to share experiences, glean deeper understandings of operational practices, and explore opportunities for collaboration. Through these exchanges and interactions, groups adapted and refined the pocket market model to suit their particular circumstances.

We contacted all groups with requests for projectrelated reports and summaries, customer surveys, and financial reports. After analyzing the materials provided to us, we conducted semi-structured interviews with representatives of the four groups operating pocket markets in metro Vancouver, as well as a representative from FoodRoots. In addition, we conducted interviews with several farmers who participated in selling their food to pocket market organizers, and who also are involved with direct marketing at farmers' markets, through farm gate sales, and/or as part of local food distribution networks. We analyzed these interviews for convergent and divergent themes. Finally, both authors have been active participants in developing farmers' and pocket markets in metropolitan Vancouver and have drawn on this experience as well.

All groups involved in testing the pocket market model in metro Vancouver have social action as part of their mandates, with local food as a particular focus. As table 1 (next page) indicates, the motivations behind operating a pocket market vary among the groups. The Richmond Food Security Task Force, the Westside Food Security Collaborative, and to a lesser degree the Surrey Urban Farmers Market were primarily focused on addressing the food needs of vulnerable populations. For the Richmond Food Security Task Force, pocket markets offered a "feasible way to support local food and provid[e] food to difficult to reach neighborhoods" (A. Hamir, personal communication, December 14, 2009). Similarly, the Westside Food Security Collaborative was acting on a research study that showed that food insecurity was a real, yet largely hidden, issue within a wealthy enclave in the city of Vancouver, especially among the population of seniors (Pottery \& Jinkerson, 2007). For the third group operating pocket markets, the Coquitlam Farmers Market Society, the motivation was to provide local food to areas where a full farmers' market may prove unfeasible. By targeting students, office workers, and the general public who frequent community facilities, this group focused on better connecting middle-class consumers with local food options. In Surrey, piloting a pocket market at a seniors' centre allowed for the provision of fresh produce to underserved populations, especially seniors, refugees, and new immigrants.

Most groups studied were explicitly committed to securing local produce from within their own municipality as a first priority and within the wider region as a secondary priority. The Coquitlam Farmers Market Society and the Surrey Urban Farmers Market were able to draw on their farmers' market vendor base to make purchasing arrangements. The Richmond Food Security Task Force and the Westside Food Security Collaborative approached area farmers to secure local produce for sale. The Richmond group also sourced local foods from a produce distribution company when extra supply was needed. While all pocket markets sold exclusively local produce, there were differences between the markets in regard to their support of local producers whose growing methods and practices fell along a spectrum that ranged from organic to spray- or pesticide-free, to conventional. While providing only organic produce may help to support a more sustainable food system, organics also tended to be more expensive and therefore potentially inaccessible to people with limited incomes. For example, the Richmond pocket market chose not to carry organic produce in part because of issues of financial accessibility for their customers (A. Hamir, personal communication, December 14, 2009). Similarly, the 
Table 1: Comparison of Pocket Markets, Metropolitan Vancouver

\begin{tabular}{|c|c|c|c|c|}
\hline & $\begin{array}{l}\text { Richmond Food } \\
\text { Security Task Force }\end{array}$ & $\begin{array}{l}\text { Coquitlam Farmers } \\
\text { Market Society }\end{array}$ & $\begin{array}{c}\text { Westside } \\
\text { Food Security } \\
\text { Collaborative }\end{array}$ & $\begin{array}{c}\text { Surrey Urban } \\
\text { Farmers Market }\end{array}$ \\
\hline $\begin{array}{l}\text { Description of } \\
\text { organization }\end{array}$ & $\begin{array}{l}\text { Subcommittee of a } \\
\text { not-for-profit society }\end{array}$ & Not-for-profit society & Community group & Not-for-profit society \\
\hline $\begin{array}{l}\text { Target } \\
\text { Audience(s) }\end{array}$ & $\begin{array}{l}\text { Low-income } \\
\text { population }\end{array}$ & $\begin{array}{l}\text { Students, office workers, } \\
\text { community members }\end{array}$ & $\begin{array}{l}\text { Low-income } \\
\text { population, } \\
\text { particularly seniors }\end{array}$ & $\begin{array}{l}\text { Seniors, refugees, } \\
\text { new immigrants }\end{array}$ \\
\hline Location(s) & $\begin{array}{l}\text { Hospital, cultural } \\
\text { centre, low-income } \\
\text { housing complexes, } \\
\text { church }\end{array}$ & $\begin{array}{l}\text { University campuses, } \\
\text { government office, } \\
\text { community centre }\end{array}$ & $\begin{array}{l}\text { Seniors centre, } \\
\text { community centre }\end{array}$ & Seniors centre \\
\hline $\begin{array}{l}\text { Number of } \\
\text { pocket markets } \\
\text { site locations }\end{array}$ & $\begin{array}{l}2008-4 \\
2009-3 \\
2010-0\end{array}$ & $\begin{array}{l}2008-1 \\
2009-4 \\
2010-3\end{array}$ & $\begin{array}{l}2009-1 \\
2010-2\end{array}$ & $\begin{array}{l}2009-1 \\
2010-0\end{array}$ \\
\hline Frequency & Weekly, seasonal & Weekly, seasonal & $\begin{array}{l}\text { Sporadically, June } \\
\text { through September }\end{array}$ & $\begin{array}{l}3 \text { markets held over } \\
\text { August and } \\
\text { September }\end{array}$ \\
\hline $\begin{array}{l}\text { Categorization } \\
\text { of local } \\
\text { produce sold }\end{array}$ & Conventional & $\begin{array}{l}\text { Organic, conventional, } \\
\text { spray/pesticide free }\end{array}$ & $\begin{array}{l}\text { Organic and/or } \\
\text { ethically grown } \\
\text { produce }\end{array}$ & Conventional \\
\hline $\begin{array}{l}\text { Prepared foods } \\
\text { offered for } \\
\text { sale? }\end{array}$ & Yes & Yes & No & Yes \\
\hline $\begin{array}{l}\text { From where } \\
\text { was food } \\
\text { sourced? }\end{array}$ & $\begin{array}{l}7 \text { local area farms } \\
\text { and from a produce } \\
\text { distribution company } \\
\text { when added supply } \\
\text { was needed. }\end{array}$ & $\begin{array}{l}\text { Primarily farmers and } \\
\text { prepared food vendors who } \\
\text { participate in the group's } \\
\text { farmers' market. Occasional } \\
\text { produce sourced from local } \\
\text { farms not involved with } \\
\text { farmers' market. Up to } 12 \\
\text { local producers' goods are } \\
\text { carried at each pocket } \\
\text { market. }\end{array}$ & 2 area farms. & $\begin{array}{l}3-4 \text { farmers and } \\
\text { prepared food } \\
\text { vendors who } \\
\text { participate in the } \\
\text { Surrey Urban } \\
\text { Farmers Market. }\end{array}$ \\
\hline Staffing & 2 part-time staff & $\begin{array}{l}1 \text { full-time and } 2 \text { part-time } \\
\text { staff plus } 2-8 \text { volunteers }\end{array}$ & $\begin{array}{l}3 \text { part-time staff and } \\
\text { up to } 9 \text { volunteers }\end{array}$ & $1-2$ volunteers \\
\hline How financed? & $\begin{array}{l}\text { Costs recovered via } \\
\text { product sales. } \\
\text { Funding received to } \\
\text { cover staffing costs. }\end{array}$ & $\begin{array}{l}\text { Costs recovered via product } \\
\text { sales. External funding and } \\
\text { sponsorship cover some } \\
\text { staffing costs. }\end{array}$ & $\begin{array}{l}\text { Costs recovered via } \\
\text { product sales. } \\
\text { Funding received to } \\
\text { defray operating } \\
\text { costs. }\end{array}$ & $\begin{array}{l}\text { Cost recovery via } \\
\text { product sales. Small } \\
\text { donation received to } \\
\text { assist with } \\
\text { purchasing produce. }\end{array}$ \\
\hline
\end{tabular}

Coquitlam Farmers Market Society's mission to support British Columbian producers without prioritizing growing practices helped them to appeal to as broad a customer base as possible. While providing conventionally grown produce for sale can allow for a lower price-point option to be extended to pocket market customers, not all pocket market organizers were willing to compromise their support of broader environmental goals, especially a commitment to sustainable farming practices, to offer this food option to the public.

Most groups sponsoring pocket markets also enhanced their product diversity by offering prepared foods (e.g., breads, salsa, jam, pickled vegetables) for sale. Prepared foods presented a double-edged sword for groups, since they had to be able to store excess product for future sale and 
take the risk, as with fresh produce, that perishable items like bread and pastries might not sell. Selling prepared foods also meant that organizers had to interface with health regulators and become familiar with the guidelines and requirements for hosting temporary food markets. These risks were weighed against the ability to provide the market shopper with a wide range of local products and a selection that enhanced the fresh produce available for sale.

Of the groups studied, most had received some level of seed funding to start up their pocket markets from health, social service, and environmental organizations. While this funding provided groups with some start-up monies, the main generator of revenue was derived from product sales at the pocket market. With small profit margins, potentially high wastage and overhead costs (transportation, storage, and staffing), it was difficult for most organizers to cover their costs. Nevertheless, a few individual pocket market locations did make modest profits. This was in large measure due to organizers being able to target a specific and identifiable customer base (e.g., at a workplace or in a university setting) with direct marketing and educational initiatives and by enhancing market-day activities with interactive displays. Having access to an identified customer base allowed organizers to provide information on upcoming markets and related educational activities, receive feedback from customers, and survey existing and potential customers about their shopping habits, preferences, and experience at market, which, according to organizers, created more interest in and utilization of the market and helped them to refine operating practices.

\section{Benefits and Challenges of the Pocket Market Model}

Pocket markets offer a creative solution for connecting urban consumers with local food as they can be seen as an addition to and/or extension of farmers' markets and other AFN initiatives. As pocket markets are an emergent model of local food distribution, they offer both benefits and challenges. They are worthy of analysis as the issue of demand putting stress on farmers' markets is a structural issue to overcome in the development of more localized food systems.

\section{Benefits of the Pocket Market Model}

According to our interviews, there are a number of benefits to operating a pocket market. These include providing additional marketing outlets for local food producers; creating opportunities to educate consumers about local food and sustainable food systems; offering convenient additional venues to consumers where they may purchase local food; and increasing access to fresh produce in areas with poor or limited food retail options.

All of the market organizers we interviewed agreed that part of their goal was to assist local producers reach a broader base of urban consumers. Unlike grocery stores or other retail produce stands, pocket markets are intended to rely on and primarily represent regional farmers and their products. Therefore, at the markets, products are labeled with their provenance and, in some instances, pictures of the farmer and/or farm, and further information about them (e.g., growing practices, years spent farming, range of products grown) is on display for customers to read. These marketing efforts allow a degree of personalization to occur around the shopping experience as consumers can become familiar with the agricultural producers and the range and quality of product they supply. This helps farmers to build and grow a targeted customer base. According to one representative of an organic cooperative that sold to the pocket markets run by the Coquitlam group, pocket markets are most beneficial to young farmers who "don't have the network developed that we have with all the markets that we go to. The pocket market could be a really valuable way for them to develop markets for their products without having to stretch themselves between a lot of farmers' markets and their fields" (C. Bodnar, personal communication, February 11, 2010). This point was echoed by a new farmer whose produce was largely being sold via the farm's CSA program and through pocket markets operated by the Coquitlam group. The farmer noted, "the pocket markets [were] excellent for us as we can't afford to be at a farmers' market for 10 hours a day very 
frequently... [and]...the high cost of insurance and our busy schedules make it difficult for us to have the public visit the farm to purchase at the farm gate." (H. Cavendish-Palmer, personal communication, October 10, 2010). Similarly, the Richmond market representative stressed that for "some [agricultural] producers who are kind of on the edge of not doing well financially, this year... [the pocket market] was a lifesaver. We were able to keep sales going, especially early in the season, when they didn't have a lot of farm-gate sales" (A. Hamir, personal communication, December 14, 2009). For more established farmers, the pocket market organizers' marketing efforts helped to develop brand identity among consumers, something that might lead to sales at farmers' markets or at their farm gate. This is particularly beneficial in an area where there are few farms and increasing demand for farmers to be at markets. As one farmer whom we interviewed explained, "We thought [pocket markets] were a really innovative idea [because] we can't go to any more [farmers'] markets" (C. Bodnar, personal communication, February 11, 2010).

Secondly, organizers viewed pocket markets as an opportunity to go into communities and educate on issues of local food and sustainable food systems. Several organizers said that part of the reason for holding a pocket market was to let people know about local food in their communities. They saw any encounter around local food as an opportunity to educate and build awareness. A few of the pocket market organizers made explicit efforts to provide information about issues surrounding local food, such as farmland preservation, farming techniques, understanding the food cycle (from seed to compost), nutrition, and seasonal cooking, through displays, activities, and newsletters or bulletins. This was most effective when done in partnership with a host organization, especially one with a sustainability mandate. For example, one university-based pocket market was closely connected to the student-run sustainability club and other on-campus environmental groups. Similarly, an office-based pocket market was seen as mutually supportive with the corporation's health and wellness mandate and was seen as a benefit to staff and a commitment to their wellbeing. This connection then provided, according to one early champion of the project, " $a$ 'vehicle' for launching awareness and education on sustainability issues that may otherwise have less impact and less connectivity" (R. Kempe, personal communication, October 1, 2010).

Furthermore, because pocket markets are more flexible and can be set up in a variety of environments (e.g., inside office buildings), they can enhance accessibility to local food. Research suggests that people tend to utilize food resources that are convenient (Blake, Mellor, \& Crane, 2010). Customer surveys conducted by the Coquitlam Farmers Market Society at a pocket market they operated in an office lobby highlighted the need for local food to be made more conveniently available for the public. One office worker stated, "This was an absolutely fantastic idea that I was extremely pleased to see happen. It's so very important to support local farmers and organic producers at that. To have such a wonderful availability right in our building was great!" This sentiment was shared by another colleague who expressed, "I really enjoyed having the market at work. I want to support local farmers and I prefer to shop locally whenever I can" (Coquitlam Farmers Market Society, 2009). From the outset, this pocket market found favor among the office workers it served. However, in Richmond, setting up a pocket market in an atypical location was more challenging. When organizers set up a pocket market in a hospital lobby, there were concerns from staff, volunteers, and the public. According to the organizer, "We had two types of naysayers. We had people who were saying, 'why are you selling food in a dirty hospital?' and then we had those that said, 'why are you bringing dirty food into the hospital?' Once people got over the idea of buying fresh vegetables at a hospital, they would time their breaks to come down and buy produce. It became quickly a popular site" (A. Hamir, personal communication, December 14, 2009).

Pocket markets have also been created to address issues of food insecurity in areas that may lack access to fresh produce due to poor or limited 
food retailing options. Studies have suggested that farmers' markets can address issues of food access and cost in low-income communities (Fisher, 1999; Larsen \& Gilliland, 2009) although they are typically targeted to more affluent communities (Slocum, 2007). Both the Richmond and Westside pocket markets were specifically designed to address the issue of food access among potentially vulnerable populations. The Westside pocket markets were created "to help address access to fresh food ... by low-income residents, especially seniors on the west side of Vancouver" (S. Gillard, personal communication, January 6, 2010). Similarly, an organizer of the Richmond markets saw its pocket markets as a form of "social support because it ... [contributed toward improved health and nutrition among residents by] providing [low income] people who live in Central Richmond with an opportunity to purchase [fresh] local food" (A. Hamir, personal communication, December 14, 2009).

\section{Challenges of the Pocket Market Model}

Interviews with pocket market organizers highlighted several challenges involved in implementing this model. These included a lack of familiarity by the public with what a pocket market is; an inability to address issues of food access in a way that was financially sustainable; and issues of logistics, site selection, and regulatory requirements.

Because pocket markets are an emerging model of local food distribution, the term is generally unfamiliar to many potential customers. Several organizers reported that customers' expectations were not met when they initially came across the pocket market, expecting to see a scaled down version of a farmers' market with its diversity of vendors and products. In assessing this difference between what was anticipated and what was encountered, it appears that community groups may have inadvertently contributed toward the identity predicament that befalls their pocket markets. The Coquitlam group began using the term "pocket farmers' market" to legitimize them as and connect them with authentic spaces of local food retailing. However in doing so they laid the groundwork for patrons to associate them with and expect the producer-direct shopping experience that a farmers' market offers. Other organizations simply used the "pocket market" label, a term that carries little resonance with the public and one that lacks identification to or connection with the fresh local product featured for sale. To overcome this challenge, organizers might consider re-branding these projects to better emphasize their niche of providing fresh local food direct from area producers. Should this option not be desirable, organizers will need to place added emphasis on public education about what a pocket market is, how its small scale works to expand the availability of local food to additional, even unexpected, locations, and how the model supports many more local producers than may be evident at first glance (see table 1 and the appendix). This focus on public education is not unlike what farmers and farmers' market organizers undertook in the mid1990s when they began to establish markets in parking lots across metro Vancouver, engaging with and educating the public around the benefits of "buying local" and watching as unconventional locations became spaces of acceptance as consumer shopping behavior slowly began to change.

Another ongoing challenge for pocket market organizers is how to address the social goal of improving access to local food with the practical need to generate sufficient revenue for the pocket markets to be financially self-sustainable. While not all pocket markets were focused on addressing accessibility issues, two of the organizations studied had an explicit goal of addressing issues of food security (or access to healthy, affordable, and culturally appropriate food) in areas that are otherwise poorly served by grocery stores or other food resources. This prioritizing of equity as the most important project goal, or as a goal on par with more traditional goals of the local food movement, shows an important and perhaps new area of emphasis. In these instances, efforts were made to provide food at an affordable cost for the intended customer base (e.g., seniors or low-income families). At the same time, pocket market organizers also wanted to provide a fair purchasing price to local producers and also price the food at a level that would also cover the costs of infrastructure, 
staffing, and transportation. In some instances, this meant that the food was too expensive for subpopulations vulnerable to food insecurity. This challenge was echoed by market organizers whose pocket markets targeted largely middle-income consumers: "the products that are carried and the price point, people in low income communities won't purchase them. Other programs such as a Harvest Box [a good food box program] are more effective [for these populations] because it has less overhead. You have economies of scale and can sell produce at a lower price point than [for what] we can buy and sell" (T. McLoughlin and A. Thebault, personal communication, March 2, 2010).

These pocket markets also faced logistical challenges. Having the quality, quantity, and diversity of product that customers want meant that pocket market organizers needed to work with a variety of producers. This required careful ordering, as any product not sold at the end of the day was typically donated to social service organizations (with the exception of the Coquitlam group, which was able to circulate some produce through several markets). However, because the quantities ordered for pocket markets were fairly small, it was sometimes difficult to ensure that farmers would be able to provide the desired produce. As one organizer put it, "in terms of priorities [for the producer], we were pretty much on the bottom...For some of the older, established farms that have a high degree of farm-gate sales, we were definitely lower on their priorities" (A. Hamir, personal communication, December 14, 2009). For producers, small orders required as much work or more to organize than large ones, and came with a smaller financial return. In one instance, an organic producer who had supplied the Coquitlam pocket markets in 2008 and 2009 decided to not continue with their markets in 2010 because "it got to the point where that for the size of the orders, it was a tremendous amount of work...we spread ourselves too thin, too quickly" (C. Bodnar, personal communication, February 11, 2010).

Another logistical issue for pocket market organizers related to the infrastructure required to mount the markets. Most pocket markets are small in scale and have limited storage, personnel, or transportation infrastructure. Many rely on a small complement of staff and volunteer workers and have made arrangements with other organizations or individuals to provide or share storage and transportation. For instance, the Coquitlam Farmers Market Society and the Richmond Food Security Task Force both established partnerships with their local food bank that provided storage facilities and use of a truck in exchange for donations of fresh produce, which is often in short supply from charitable food providers. Also, because some farmers were unable or unwilling to deliver their produce directly to pocket market sites, pocket market personnel spent a good deal of time driving out to farms to pick up orders, thus increasing both transportation and staffing costs. In addition, this lack of infrastructure means that pocket markets are vulnerable if these external resources are lost.

Identifying appropriate sites was also a challenge for many market organizers, and there was little consensus among them about what made a good pocket market site. In metro Vancouver, pocket markets have been held in a number of locations, including community and seniors' centers, office buildings, health-care facilities and university campuses. These sites were typically chosen because they had a large number of potential customers in close proximity, good access to public transportation, and/or were easily accessed by a particular population (e.g., seniors, students). Attention was also paid to the location of potential competition, typically in the form of conventional produce stands, grocery stores, or in the case of one market, on-farm sales. While it is important to find a site with high foot traffic, it was also noted that not all busy locations were necessarily well suited as a pocket market site. For instance, one pocket market organizer noted that while the market was situated within an area with high transit access, its location was not sufficiently visible to attract transit users to the market. Similarly, locating a pocket market in an office building meant that organizers needed to be aware of staffing hours, employees' ability to store produce near or at their desks after 
they have bought it, as well as have access to methods of communication with staff (via internal email networks or presence on a company website) in order to advertise and promote the market directly and regularly.

Finally, because pocket markets do not fit into established categories designed to regulate food retail, they have experienced regulatory barriers. Some organizers reported that they had difficulties meeting health regulations and were therefore limited in what they could sell. Since pocket markets are a new concept, health authority representatives did not always interpret and apply the guidelines for temporary food markets in the same manner. This left some market organizers unclear at times about what was required in terms of health regulation. For instance, one market organizer reported that" [Vancouver] Coastal Health made us put up signs to the effect that our produce hadn't been washed and you needed to wash it before consuming" (A. Hamir, personal communication, December 14, 2009). This was not a requirement for pocket markets operating in jurisdictions governed by a neighboring health authority. It was also observed that organizers who also operated farmers' markets experienced fewer challenges in this regard. They had a higher degree of familiarity with and experience in dealing with health authority policies, guidelines, and expectations, and seemed more nimble at meeting the administrative requirements when it came to their pocket markets.

Organizers also had to be aware of municipal-level regulatory requirements when establishing their pocket markets. Municipal governments have a number of ways in which they can regulate efforts to improve food access (e.g., mobile and pocket markets, food carts, farmers' markets), which can enable or constrain these enterprises (Morelas \& Kettles, 2009; Tester, Stevens, Yen, \& Laraia, 2010). For instance, the degree to which municipalities enforced their signage bylaws impacted pocket markets differently. A pocket market operating at one suburban community centre was rendered largely invisible when the enforcement of municipal signage bylaws meant that organizers could not post signage in the immediate vicinity of the market. Despite attempts to find a middle ground with municipal staff, the inability to advertise directly to the community played a large role in the discontinuation of that pocket market. Conversely, in a different municipality where signage bylaws were not enforced as stringently, this was a non-issue for organizers.

Pocket market organizers also had to navigate other municipal requirements. In one municipality, grassroots-level, commercially oriented local food initiatives are subject to a comprehensive approval process that involves site assessments by municipal and health authority regulators and the levying of municipal fees and charges that may be costprohibitive to continuing such small-scale projects. Further, a couple of organizers also reported that an extended approval process was necessary to overcome regulation that prohibited retail activity on government property. Organizers noted that having status as an incorporated not-for-profit society, combined with a focus on sustainability and education (i.e., capacity building), were important for being able to access these environments and to mitigate concerns about competition with other food retailers.

\section{Discussion and Conclusion}

Pocket markets are a relatively new strategy for bringing locally produced food to urban populations. Organizers in metropolitan Vancouver are using the model to increase access to local food in novel locations and at the same time reducing the burden on producers to attend an ever growing number of farmers' markets. Proponents of this model, however, face many challenges to overcome for it to meet these goals. In this section we will discuss strategies to enhance the sustainability of the pocket market model.

Our study reveals that most organizations operating pocket markets find sustaining them to be a challenge given current organizational capacity and resources. This is not unlike the experience of many alternative enterprises. Most pocket markets operate on shaky financial ground due to the risks they assume in bringing local food to new markets 
and are heavily reliant on volunteer resources and in-kind exchanges to implement and operate their markets. Organizations looking to operate a pocket market need to first make the business case for engaging in such an endeavor. This would be helped by developing, prior to implementation, a business plan that clearly sets out the rationale for the project, establishes revenue targets, and balances these with expense estimates so that the financial viability of the project remains in the forefront.

In addition, prior to starting a pocket market, organizations need to understand and establish protocols and processes around where and how to source products, how logistics (storage, transportation, and tracking of inventory) will be coordinated, what marketing tools and initiatives will be employed to promote the markets, how the consumer base will be educated on the products and producers represented at market, and how mutually beneficial relationships (e.g., with local producers, host organizations or communities, municipal and health regulators) can be fostered to grow markets in new locations. Organizations could also benefit from developing criteria and/or indicators for evaluating the success and shortcomings of their projects across locations and from year to year. Information that would be useful to track includes expense and revenue data, including the cost of staffing, transportation, storage, and purchasing product, sales data (including number of transactions, order vs. sales ratios, amount of revenue generated), and information gleaned through end-of-season surveys of customers and producers. Doing so would assist organizations in developing best practices and implement more efficient systems for operating their markets.

As revealed through the interviews, organizers also need to develop sound rationales for the siting of pocket markets. Several markets in this study were unsuccessful in part due to issues with location. There is currently little in the way of best practices on what constitutes a good site for a pocket market. Typically organizers are invited to do a market at a particular location by community members or an organization interested in hosting a market. However, without a thorough needs assessment, this may prove to be a waste of resources as such a site may turn out to be poor. Having site selection criteria would enhance the success of pocket markets and reduce the locational risk and uncertainty that at present seem to be contributing factors to financial losses. The need for this also speaks to a wider point: the pocket market model in metro Vancouver remains in the testing and adaptation stage and has yet to reach a point of settlement and stability. Once this has occurred, an evaluation of the model can be undertaken and best practices established.

As the local food movement grows, the issue of scale becomes important (Born \& Purcell, 2006). In some places like metropolitan Vancouver, the appetite for local food has grown beyond the current capacities of producers who are interested in selling at farmers' markets. At the same time, for consumers, the accessibility of local food is often limited to a weekly farmers' market. Pocket markets provide accessible places for consumers to purchase food from local farmers without the need for direct participation of those farmers. They introduce consumers to the idea of purchasing local food "where they are," be it in their neighborhood or at their workplace. At the same time, pocket markets provide producers, especially farmers, with additional outlets across the region where they may market added quantities of their food and to do so in an environment that offers low risk and little cost for their participation. Pocket markets are also an alternative to mainstream retail outlets that often demand a particular quality and/or quantity of produce that in most cases prohibits the participation of small producers.

The future viability of pocket markets hinges on a number of factors, including developing more refined business practices, the continued demand for local food, and increased participation of small and medium-sized farmers in the region. Pocket markets have the potential to fill a niche in the alternative food network and provide benefits for farmers, consumers, and community organizers. 


\section{Acknowledgements}

The authors would like to thank representatives from the organizations under study for helping us to understand their motivations and practices. Thanks also to Eugene McCann, Peter V. Hall, Jonathan Fershau, and the anonymous JAFSCD reviewers for their valuable insights on earlier versions of this paper. We acknowledge and thank Simon Fraser University's Urban Studies program (Anthony Perl) and the Urban Affairs Association for funding received to present preliminary findings from this study at the 2010 UAA conference. All the usual disclaimers apply.

\section{Disclosures}

Both authors have been directly involved with developing farmers' markets and pocket markets in metro Vancouver. They currently serve on the board of the Coquitlam Farmers Market Society. 


\section{Appendix}

Sample Range of Product Available for Sale at a Pocket Market in Metropolitan Vancouver, 2009

Farm-fresh products

Apples, apricots, beans, beets, bok choy, blueberries, broccoli, cabbage, carrots, celery, chard, cherries, cherry tomatoes, cilantro, corn, cucumbers, dill, fennel, free range organic eggs, green butter lettuce, green leaf lettuce, green onions, hazelnuts, jalapenos, kale, mizuna, mustards, oyster mushrooms, shitake mushrooms, portabella mushrooms, parsley, peaches, pears, peas, peppers, potatoes, plums, radishes, raspberries, red butter lettuce, red leaf lettuce, red oak lettuce, rhubarb, romaine lettuce, salad mix, spinach, squash, strawberries, vine tomatoes, zucchini.

Baked and prepared foods

Assorted breads and buns, strudel, cinnamon twists, cheese pretzels, granola, buns, salsa, lemonade syrup, honey, assorted jams and jellies, spicy dills, dill pickles with garlic, pickled beans, bread and butter pickles. 


\section{References}

Alkon, A. (2008). Paradise or pavement: The social constructions of the environment in two urban farmers' markets and their implications for environmental justice and sustainability. Local Environment, 13(3), 271-289. doi:10.1080/13549830701669039

Blake, M., Mellor, J., \& Crane, L. (2010). Buying local food: Shopping practices, place and consumption networks in defining food as "local." Annals of the Association of American Geographers, 100(2), 409-426. doi:10.1080/00045601003595545

Born, B., \& Purcell, M. (2006). Avoiding the local trap: Scale and food systems in planning research. Journal of Planning Education and Research, 26, 195-207. doi:10.1177/0739456X06291389

Connell, D. J., Smithers, J., \& Joseph, A. (2008). Farmers' markets and the "good food" value chain: A preliminary study. Local Environment, 13(3), 169185. doi:10.1080/13549830701669096

Coquitlam Farmers Market Society. (2009). Metro Market Survey.[Unpublished survey]

Coquitlam Farmers Market Society. (2010). 2009 Pocket Market report. Unpublished report.

Fisher, A. (1999). Hot Peppers and Parking Lot Peaches. Evaluating Farmers' Markets in Low-Income Communities. Community Food Security Coalition.

FoodRoots Distributors Cooperative. (n.d.) The Pocket Market Toolkit. Retrieved from http://foodroots.ca/pmtoolkit index.htm

Jarosz, L. (2008). The city in the country: Growing alternative food networks in Metropolitan areas. Journal of Rural Studies, 24, 231-244. doi:10.1016/i.jrurstud.2007.10.002

Larsen, K., \& Gilliland, J. (2009). A farmers' market in a food desert: Evaluating impacts on the price and availability of healthy food. Health \& Place, 15:1158-1162. doi:10.1016/j.healthplace.2009.06.007

Ling, C., \& Newman, L. (2010). Garlic and granola: Food webs and the catchment of farmer's markets from the food producers' perspective. Paper presented at the Canadian Association of Food Studies Meeting, Montreal.
MacAdam, R. (2009, November/December). Local hero: Lee Fuge of FoodRoots. EAT Magazine. Retrieved from http://www.eatmagazine.ca/ heroes/2009-11-01/leefuge

Morales, A., \& Kettles, G. (2009). Healthy food outside: Farmers' markets, taco trucks and sidewalk fruit vendors. Journal of Contemporary Health Law and Policy 20, 20-48.

North, W. N. (1969). Small Urban Spaces: The Philosophy, Design, Sociology and Politics of Vest-Pocket Parks and Other Small Urban Spaces. New York: New York University Press.

Pollan, M. (2006). The Omnivore's Dilemma: A Natural History of Four Meals. New York: Penguin Press.

Pottery, H. \& Jinkerson, A. (2007). Exploring Food Security in V ancouver's Westside. Unpublished report prepared for the Westside Food Security Collaborative.

Richmond Food Security Task Force. (2008). Richmond Pocket Market Report. Unpublished report.

Slocum, R. (2007). Whiteness, space and alternative food practice. Geoforum, 38(3), 520-533. doi:10.1016/j.geoforum.2006.10.006

Statistics Canada. (2006). GVRD Population and Private Dwellings, 2006 Census. Retrieved from http://www.metrovancouver.org/about/statistics/ Pages/KeyFacts.aspx (see Population: Census 2006 Population and Dwelling Counts).

Surrey Urban Farmers Market. (2009). 2009 Pocket Market Review. Unpublished report.

Tester, J. M., Stevens, S. A., Yen I. H., \& Laraia, B. A. (2010). An analysis of public health policy and legal issues relevant to mobile food vending. American Journal of Public Health. Advance online publication. doi:10.2105/AJPH.2009.185892

Vallianatos, M., Gottlieb R., \& Haase, M. A. (2004). Farm-to-school: Strategies for urban health, combating sprawl and establishing a community food systems approach. Journal of Planning Education and Research, 23, 414-423. doi:10.1177/0739456X04264765

Westside Food Security Collaborative. (2009). Pocket Market Pilot Program report. Unpublished report. 